\title{
A substance in honey bee larvae inhibits the growth of Paenibacillus larvae larvae
}

\author{
Manuela WedENIG, Ulrike RIESSBERGER-GALLÉ, Karl CRAILSHEIM* \\ Institut für Zoologie an der Karl-Franzens Universität Graz, Universitätsplatz 2, 8010 Graz, Austria
}

(Received 3 August 2001; revised 1 May 2002; accepted 14 June 2002)

\begin{abstract}
Paenibacillus larvae larvae, a Gram-positive and spore-forming bacterium, is the cause of American foulbrood. We investigated the resistance of larvae of different ages from different colonies against $P$. larvae larvae. We prepared ethanol-water-extracts from two, three, four and five day old larvae and also larvae in two capped stages to test the ability of the homogenates to inhibit the growth of $P$. larvae larvae in vitro. There were age and colony dependent differences in the inhibiting potentials of larvae. The results suggest that the concentration of the inhibiting substance(s) in the extract might be responsible for the known different degree of resistance against $P$. larvae larvae in vivo. Our results further show that the extracts of the two-, three- and four-day-old larvae have the ability to inhibit the growth of $P$. larvae larvae very well, while starting around day five the inhibiting effect is gradually reduced.
\end{abstract}

Apis mellifera carnica / Paenibacillus larvae larvae / honeybee larvae / age-related resistance /

\section{INTRODUCTION}

Paenibacillus larvae subspecies larvae, formerly Bacillus larvae (Heyndrickx et al., 1996), a Gram-positive, spore-forming bacterium, is the causative agent of the American foulbrood, one of the most serious and destructive brood diseases of honeybees. Different honey sample investigations (Hansen, 1984b; Grimm and Mossbeckhofer, 1993) demonstrate that AFB is a problem for beekeepers world-wide.

One hypothesized mechanism of resistance is built on genetically-based adult behavior. Rothenbuhler (1964), Rothenbuhler and Thompson (1956) and Bamrick and Rothenbuhler (1961), Bamrick $(1964,1967)$ investigated differences between various genetic lines of honeybees. They distinguished between resistant and susceptible lines and were able to find differences between the lines in their removal of AFB-infected brood or hygienic behavior. The resistant colony removed the dead brood completely, while the susceptible colony allowed some damaged brood to remain in the cells (Rothenbuhler, 1964).

Another hypothesized mechanism centers on physiological features of the larvae. Rothenbuhler (1964), Rothenbuhler and Thompson (1956) and Bamrick and Rothenbuhler (1961), Bamrick (1964, 1967) also found differences in resistance among individual larvae between the resistant and susceptible colonies, in contrast to work by Woodrow (1942), who reported that colony resistance did not depend on larval resistance.

However, Rothenbuhler and Thompson (1956) showed that the larvae of different lines had different survival rates following inoculation with spores of $P$. larvae larvae. After the same treatment with spores, Bamrick and Rothenbuhler (1961) determined that two genetic lines differed in the age the larvae became resistant against the infection. Larvae of the resistant line became resistant after about 36 hours of age, while the larvae of the susceptible line did not become resistant until about 48 hours.

\footnotetext{
* Correspondence and reprints

E-mail: karl.crailsheim@kfunigraz.ac.at
} 
A further hypothesis is that the ingredients of the larval food (synthesized by nurse bee or collected by foragers) or other substances have an influence on the resistance of larvae against P. larvae larvae.

Woodrow and Holst (1942) demonstrated that larvae older than two days were less susceptible to an infection with AFB. Haydak (1943) showed that the composition of the larval food changed during larval development. On the basis of these two facts, it was assumed that there was a connection between larval food and resistance.

Sturtevant (1924) showed that spores of $P$. larvae larvae were not able to germinate at high concentrations of reducing sugars. But this result was disproved by Tarr (1937), who noticed a spore germination at even higher reducing sugar concentrations than reported by Sturtevant.

Rinderer and Rothenbuhler (1974) demonstrated the influence of pollen on the mortality of spore-fed larvae. Pollen contains microorganisms which act as antagonists of $P$. larvae larvae (Brødsgaard et al., 1998). The presence of pollen in the intestine of the larvae may act to inhibit P. larvae larvae (Reiche et al., 1996). Bíliková et al. (2001) reported that royalisin, a peptide fraction of royal jelly (the food of queen larvae) was found to inhibit the growth of $P$. larvae larvae. Other investigated substances include various saturated and unsaturated free fatty acids (Feldlaufer et al., 1993), which were found to have antibiotic activity.

The aim of the present work was to elucidate the age related presence of $P$. larvae larvae growth inhibiting substances in larvae, especially in the larvae described as becoming increasingly resistant at the age of about 48 hours.

\section{MATERIALS AND METHODS}

\subsection{Paenibacillus larvae larvae}

\section{Cultivation and identification of Paenibacillus larvae larvae}

For our investigations we cultivated a fresh $P$. larvae larvae culture from an infected colony in
Styria (Austria). We took material from a contaminated brood comb and platted it on a Columbia sheep blood agar (27.3 g Columbia agar base $\left(\mathrm{Oxoid}^{\circledR}\right), 700 \mathrm{ml}$ distilled water, $50 \mathrm{ml}$ sheep blood). Grown bacterial cultures were transferred (after 3 days at $37^{\circ} \mathrm{C}$ ) from the plate to a liquid medium (brain-heart-infusion $\left(\mathrm{Oxoid}^{\circledR}\right)$ ) and incubated for 48 hours at $37^{\circ} \mathrm{C}$, and then $1 \mathrm{ml}$ aliquots of the identified $P$. larvae larvae suspension were frozen at $-70{ }^{\circ} \mathrm{C}$ until use.

The identification of $P$. larvae larvae was made with the catalase-test (Haynes, 1972) on Columbia agar and with the "Plageman" test on Columbia sheep blood slant agar (Plageman, 1985).

Starting a new experimental series, we inoculated $40 \mathrm{ml}$ autoclaved brain-heart-infusion with $1 \mathrm{ml}$ defrosted bacteria suspension. After a heat-shock at $77^{\circ} \mathrm{C}$ for $10 \mathrm{~min}$, we incubated the suspension for 48 hours at $37^{\circ} \mathrm{C}$. After this time the suspension reached an optical extinction of $0.22-0.23$ measured at a wavelength of $546 \mathrm{~nm}$.

The optical extinction was used as a measure for the turbidity of the suspension and therefore as one for the bacterial growth.

\subsection{Colonies and samples}

The samples for our investigations were taken from six different full sized (two or three stories) colonies, with approximately 35000 bees, during August 2000. The hives stood side-by-side in one beeyard, so that we could exclude external influences, e.g. different weather conditions.

Samples from the honey stores of each colony were examined for spores of $P$. larvae larvae (Hansen, 1984a, b; Hornitzky and Karlovskis, 1989; von der Ohe and Dustmann, 1997). Our analysis did not show any presence of $P$. larvae larvae spores.

\subsubsection{Sampling the larvae}

We sampled larvae of different weight classes. In preliminary experiments, we caged queens to determine the age and relative weights of larvae (see Fig. 1a). We then compared our data with data from the literature (Stabe, 1930; Wang, 1965) and together with known morphological parameters, e.g. size (Myser, 1954), we could estimate the age of the larvae by its weight. For the present experiment, we set up six weight classes consisting of larvae with an average weight of $2.25 \mathrm{mg}$, $20.5 \mathrm{mg}, 46.3 \mathrm{mg}, 132.8 \mathrm{mg}, 134.8 \mathrm{mg}$ respectively $136.6 \mathrm{mg}$ (see Fig. 1b). These six weight classes correspond to six age classes (see Fig. 1b). Hereafter, we refer to the age classes of the larvae, based on their weights. 


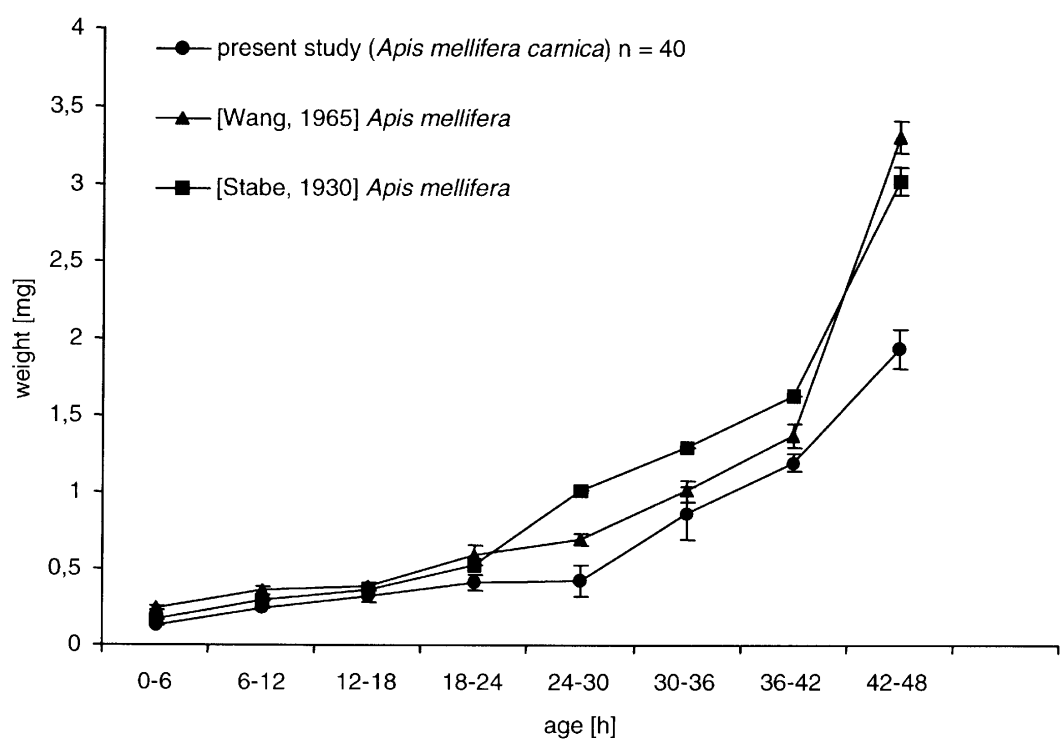

(a)

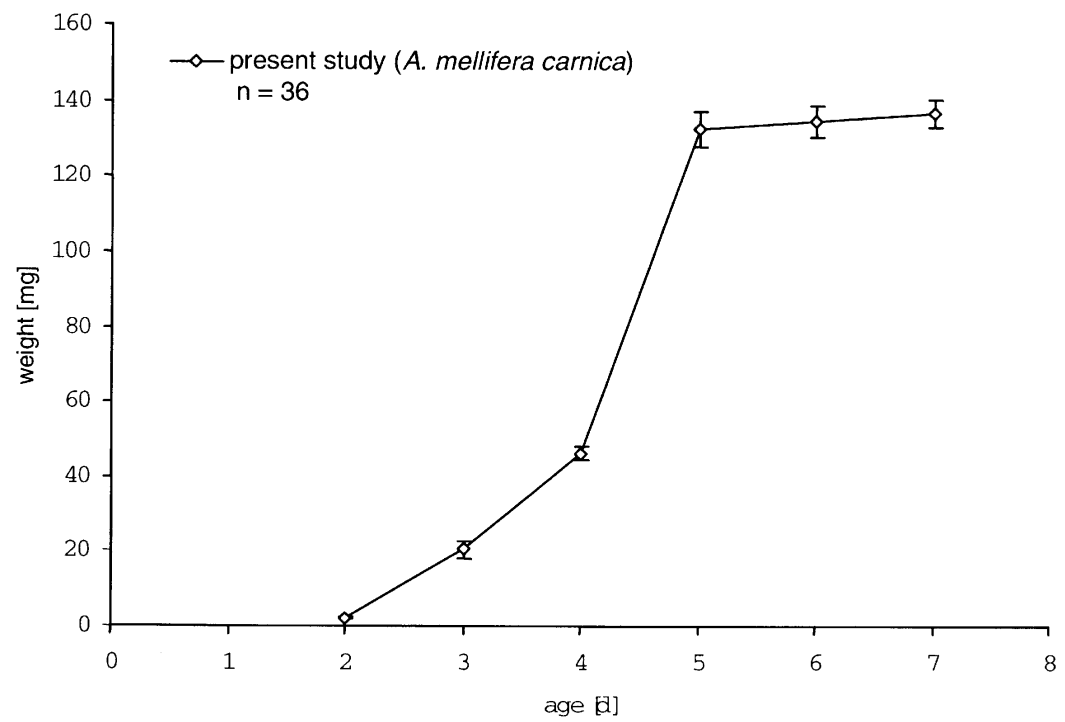

(b)

Figure 1. (a) Growth of the honeybee larvae (average of four different colonies) between 0-48 hours of larval development. The age of the larvae in the present study was determined by keeping the queen caged for egg laying. The compared data are from Stabe (1930) and Wang (1965). (b) Growth of honeybee larvae (the average from six colonies) between the second and seventh day of larval development. The age of the larvae in the present study (shown here) is an estimated age, based on their weight and size. 
Larvae were removed from the brood combs and washed with distilled water, then touched dry with filter paper. For each sample (always about $130 \mathrm{mg}$ larval tissue) we either put several young larvae, or only one old larva (five, six and seven day old) into an Eppendorf vial, added $50 \mu \mathrm{L}$ distilled water, homogenized them ultrasonically and finally added $400 \mu \mathrm{L}$ ethanol (96\%). Then the samples were frozen at $-70{ }^{\circ} \mathrm{C}$. Prior to use, they were thawed for approximately 24 hours at $4{ }^{\circ} \mathrm{C}$, centrifuged, and the supernatants were lyophilized.

The lyophilized extracts were stored at $4{ }^{\circ} \mathrm{C}$ for a possibly short period until use.

\subsubsection{Larvae-weight and growth inhibition}

From each colony used $(n=6)$, six larval age groups were investigated. In each colony, one agegroup comprised of six samples $(n=6$; except the two-day-old larvae of colony 4 in which $\mathrm{n}=5$; in colony $6, n=3$; and in colony $7, n=4$ ). In case of the five, six and seven day old larvae, single individuals were used. Younger larvae had to be pooled until a sample weight of about $130 \mathrm{mg}$ was obtained. Although intended, the weight of larvae used for each sample was not exactly the same. To exclude that such an inexactness might have caused differences, we tested whether there was a correlation between the weight of the larvae used to generate a sample and the anti Paenibacillus larvae larvae-activity of the pools. There was no such a correlation, indicating our pooling method to be valid.

\subsection{Experimental setup}

The method established by Crailsheim and Riessberger-Gallé (2001) was used to test the antibacterial activity of the larval extract against $P$. larvae larvae.

The lyophilized samples (see above) were dissolved in $200 \mu \mathrm{L}$ sterile water and different concentrations of the solution were added to test tubes filled with $1 \mathrm{~mL}$ liquid culture medium (brainheart-infusion $\left(\right.$ Oxoid $\left.^{\circledR}\right)$ ). The dilution series consisted of five different concentrations of each larval extract corresponding $32.5 \mathrm{mg}$ to $2.03 \mathrm{mg}$ larval extract; the addition of the redissolved extracts did not change the $\mathrm{pH}$ of the culture medium (7.2). Sterile water was used as control for normal growth of $P$. larvae larvae. For each dilution steps two test tubes were used. Both were filled with $1 \mathrm{ml}$ brain-heart infusion and the same concentration of larval extract. One of the two test tubes was inoculated with $30 \mu \mathrm{L}$ of $P$. larvae larvae suspension with a defined optical extinction $(\mathrm{E}=$ $0.22-0.23$ measured at a wavelength of $546 \mathrm{~nm}$ ).
The second test tube was used as control for unintended bacterial and fungus growth and also served as a blank during later photometrical measurements (wavelength: $546 \mathrm{~nm}$ ).

All test tubes were incubated under aerobic conditions at $37{ }^{\circ} \mathrm{C}$ (a temperature at which $P$. larvae larvae grow best (Haynes, 1972)) for 24 hours and shaken before photometrical measurement.

For logistic reasons it was necessary to investigate each colony in two steps. So we tested the two-, four- and six-day-old larvae together in one experimental series and three-, five- and sevenday-old larvae in a different series.

Negative growth inhibition data were calculated if the optical extinction (measured at a wavelength of $546 \mathrm{~nm}$ after 24 hours of aerobically incubation at $37^{\circ} \mathrm{C}$ ) was higher in larval extract samples compared to the reference sample with sterile water.

\subsection{Statistics}

Means and standard deviations are given. The percent growth inhibition between all six colonies was tested for differences with the Kruskal-Wallis H-Test.

The percent growth inhibition of the different colonies at certain larval ages (two, three and five day old larvae) were tested for differences using a Mann-Witney U-Test. The level of significance was set at $P<0.05$.

\section{RESULTS}

\subsection{Different larval ages}

The growth inhibiting effect was age related; different larval ages are able to inhibit the growth of the vegetative form of $P$. larvae larvae to different extents (Fig. 2).

The equivalent of $32.5 \mathrm{mg}$ larval extract (the highest concentration in our experimental set-up) of the two-, three- and four-day-old larvae had the greatest potential to inhibit the growth of $P$. larvae larvae. There were variations in inhibition among identical age classes taken from different colonies; the differences ranged from $64 \%$ to $84 \%$ in the two day old larvae, $73-86 \%$ in the three-day-old ones, and $68-85 \%$ in the four-day-old larvae. The ability to inhibit the bacterial growth with extracts of five-day-old larvae, the last uncapped larval stage, decreased significantly, compared to the two-day-old larvae (in all colonies except in 


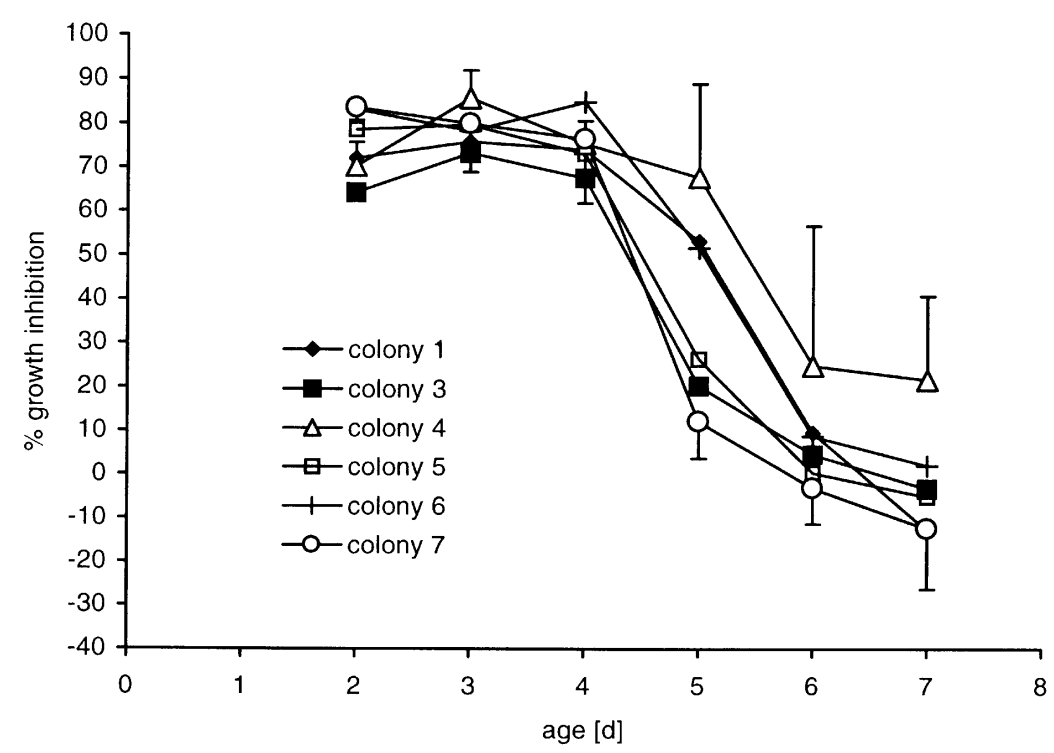

Figure 2. Percent growth inhibition (optical extinction measured at a wavelength of $546 \mathrm{~nm}$ after 24 hours of aerobic incubation at $37^{\circ} \mathrm{C}$ ) of the equivalent of $32.5 \mathrm{mg}$ of larval extract. Six different larval ages from six colonies were analysed. For significant differences of the five day old larvae see Table Ia.

colony 4). Significant differences were found in the growth inhibition of the five-day-old larvae among the six investigated colonies. While the larvae from colonies 1, 4 and 6 had approximately the same inhibition potentials as the three younger stages, the larval extract of the colonies 3,5 and 7 had nearly no potential to suppress the growth of $P$. larvae larvae. Differences are shown in Table Ia.

Table I. (a) Differences between the six colonies in the percent growth inhibition of the equivalent $(32.5 \mathrm{mg}$ ) of the larval extract of five day old larvae, (n.s. = not significant). (b) Differences between the six colonies in the percent growth inhibition of the equivalent $(2.03 \mathrm{mg})$ of the larval extract of two day old larvae, (n.s. = not significant). (c) Differences between the six colonies in the percent growth inhibition of the equivalent $(2.03 \mathrm{mg})$ of the larval extract of three day old larvae, (n.s. = not significant).

Ia

\begin{tabular}{|c|c|c|c|c|c|c|}
\hline & 1 & 3 & 4 & 5 & 6 & 7 \\
\hline 1 & -- & $P>0.05$ & n.s. & $P>0.05$ & n.s. & $P>0.01$ \\
\hline 3 & $P>0.05$ & -- & $P>0.05$ & n.s. & $P>0.05$ & n.s. \\
\hline 4 & n.s. & $P>0.05$ & -- & $P>0.05$ & n.s. & $P>0.01$ \\
\hline 5 & $P>0.05$ & n.s. & $P>0.05$ & -- & $P>0.05$ & $P>0.05$ \\
\hline 6 & n.s. & $P>0.05$ & n.s. & $P>0.05$ & -- & $P>0.01$ \\
\hline 7 & $P>0.01$ & n.s. & n.s. & $P>0.05$ & $P>0.01$ & -- \\
\hline
\end{tabular}

Table I. (continued).

Ib

\begin{tabular}{|c|c|c|c|c|c|c|}
\hline & 1 & 3 & 4 & 5 & 6 & 7 \\
\hline 1 & -- & n.s & n.s. & n.s & n.s. & n.s \\
\hline 3 & n.s. & -- & n.s. & n.s. & n.s. & n.s. \\
\hline 4 & n.s. & n.s. & -- & $P>0.05$ & n.s. & $P>0.05$ \\
\hline 5 & n.s. & n.s. & $P>0.05$ & -- & n.s. & n.s. \\
\hline 6 & n.s. & n.s. & n.s. & n.s. & -- & n.s. \\
\hline 7 & n.s. & n.s. & $P>0.05$ & n.s. & n.s. & -- \\
\hline
\end{tabular}

Ic

\begin{tabular}{|c|c|c|c|c|c|c|}
\hline & 1 & 3 & 4 & 5 & 6 & 7 \\
\hline 1 & -- & n.s & $P>0.05$ & $P>0.05$ & $P>0.01$ & $P>0.05$ \\
\hline 3 & n.s. & -- & $P>0.05$ & $P>0.05$ & $P>0.01$ & $P>0.05$ \\
\hline 4 & $P>0.05$ & $P>0.05$ & -- & $P>0.05$ & n.s. & n.s. \\
\hline 5 & $P>0.05$ & $P>0.05$ & $P>0.05$ & -- & n.s. & n.s. \\
\hline 6 & $P>0.01$ & $P>0.01$ & n.s. & n.s. & -- & n.s. \\
\hline 7 & $P>0.05$ & $P>0.05$ & n.s. & n.s. & n.s. & -- \\
\hline
\end{tabular}

The six- and seven-day-old larvae - which are already capped in their brood cells showed practically no inhibiting effect on average (exception: colony 4 ).

Despite the differences between the colonies at certain larval ages (see above), there 


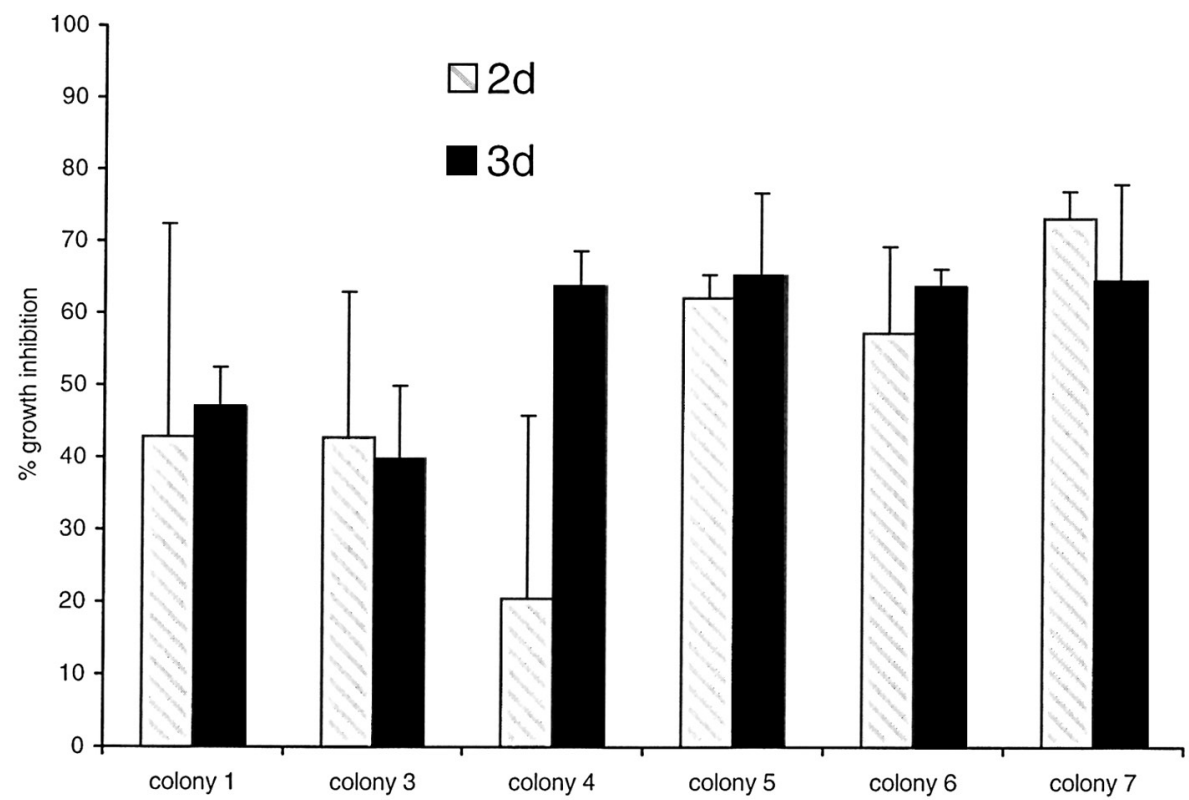

Figure 3. Percent growth inhibition (optical extinction measured at a wavelength of $546 \mathrm{~nm}$ after 24 hours of aerobic incubation at $37^{\circ} \mathrm{C}$ ) of the equivalent of $2.03 \mathrm{mg}$ of the larval extract. Two different larval ages from six colonies were analyzed. For significances of the two day old larvae see Table $\mathrm{Ib}$ and for significances of the three day old larvae see Table Ic. There are no significant differences between the percent growth inhibition of the extracts of the two and three day old larvae of each colony.

were no significant differences when we compared the total age curves of the six colonies in general (Kruskal-Wallis H-Test; Fig. 2).

\subsection{Different growth inhibition of two different larval ages}

We also tested whether there were differences in the resistance against $P$. larvae larvae within and between the investigated colonies at two different young larval ages. Two- and three-day-old larvae - being on the threshold of resistance - were tested, and the percent growth inhibition of an equivalent of $2.03 \mathrm{mg}$ larval extract was compared (2.03 $\mathrm{mg}$ is about the weight of a two-day-old larva). There were no differences between the extracts of the twoand three-day-old larvae within each colony (Fig. 3).

Within the two-day-old larvae, significant differences were found between colony 4 and colony 5 as well as between colony 4 and colony 7 (Tab. Ib).
Several significant differences among the three-day-old larvae are shown in Table Ic.

\section{DISCUSSION}

Crailsheim and Riessberger-Gallé (2001) found that larvae, and particularly adult honeybees, had heat-resistant substances in their midgut, which had the ability to inhibit the growth of $P$. larvae larvae in vivo.

In the present work, we tested the time course of resistance (the affectivity of antibacterial substances) in the larvae. The three youngest larval ages investigated, the two-, three- and four-day-old larvae, inhibited the growth of $P$. larvae larvae to the highest extent (Fig. 2). Although we used larval extracts, we can assume that larvae would have a good resistance against an infection in vivo because data from the literature (Woodrow and Holst, 1942; Bailey and Lee, 1962; Bamrick, 1967) show that young larvae (two-, three- and fourday old) have increasing resistance with increasing age. There are different explanations 
found in the literature for why larvae are resistant. Some authors (Sturtevant, 1924; Rinderer and Rothenbuhler, 1974) have the opinion, that the resistance of larvae against AFB has something to do with the chemical composition of larval food and its changes during larval development (Haydak, 1943). For example, Sturtevant found that the food of the older larvae contained a higher percentage of reducing sugar which was derived from honey or nectar, and that a concentration of reducing sugar of approximately 3 to 4 per cent or more in the larval intestine was more than sufficient to inhibit the growth of $P$. larvae larvae spores.

On the other hand Tarr (1937b) showed, that germination of the spores and multiplication of the vegetative cells took place in the presence of concentrations of reducing sugars as high as $12.5 \%$.

Rinderer and Rothenbuhler (1974) showed that the resistance against AFB was associated with the pollen consumption of the larvae. With a certain amount of pollen fed together with spores, they found decreasing mortality of larvae. It is important to take into account that the natural food of the worker larvae during the first four days of their lives contains only traces of pollen (Haydak, 1943).

Crailsheim and Riessberger-Gallé (2001) found that there was a higher growth inhibition effect of four day old larvae than could be attributable to the amount of consumed pollen. On the basis of their work, they assumed that the inhibiting substances (or substance) were produced by the honeybee larvae and by the imagos, although they could not exclude an involvement of food consumed as larvae in the development of bacterial resistance. However they could verify their assumption that the substances at least in the adults were "beemade" because even bees fed with artificial food showed midgut-located resistance. The midguts of foragers, that mainly feed on honey and nectar and thus contain only traces of pollen, have a great ability to inhibit the growth of the vegetative form of $P$. larvae larvae. (Loidl and Crailsheim, 2001; Crailsheim et al., 1992) Honey itself has no inhibiting effect at all if diluted (Riessberger-Gallé et al., 2001).

Another argument against the "food-theory", is the fact that worker jelly only has an effect on the growth of the bacteria at high concentrations.

Crailsheim and Riessberger-Gallé (2001) showed that $2 \mathrm{mg}$ of pure worker jelly had no effect, while the equivalent extract from a $2.25 \mathrm{mg}$ worker larva inhibited about 50\% bacterial growth.

The differences we found between the inhibition potentials of the individual two day old larvae (Fig. 3, Tab. 1b) were significant between colonies 4 and 5, and colonies 4 and 7 , but to determine whether the differences were a function of genetic different lines (Rothenbuhler and Thompson, 1956; Bamrick and Rothenbuhler, 1961; Rothenbuhler, 1964), more investigations would be necessary. The lines Rothebuhler and Thompson used in their investigations had been bred for resistance or susceptibility to AFB. Further, Bamrick and Rothenbuhler used lines that were bred over several generations, while we just used a variety of unselected colonies. To determine the reasons for the significant differences between the inhibition potentials of the equivalent extracts of $2.03 \mathrm{mg}$ of the three-day- old larvae (Fig. 3), more investigations would have to be performed. We think that our methods might be a good way to discriminate between resistant and susceptible lines, when the differences in resistance could be attributed to genetic differences.

The great variation between the growth inhibition of the five-day-old larvae (Fig. 1) may depend on the moment of taking the samples, whether the larvae's age was closer to the four- or to the six-day-old larvae, and therefore close to capped stage.

As we could detect different inhibiting potentials of the larval extracts from different colonies, one long-term aim of future investigations will be the differentiation between resistant and susceptible lines, followed by the exclusive breeding of resistant colonies. Another aim will be the identification of the inhibiting substances.

\section{ACKNOWLEDGEMENTS}

We thank Dr. Norbert Hrassnigg for his advise and "keeping the bees" and we also thank Mag. Ursula Platzer and Ross Little for linguistic correction of the manuscript. 
Résumé - Une substance dans les larves d'abeilles (Apis mellifera) qui inhibe la croissance de Paenibacillus larvae larvae. Paenibacillus larvae larvae, bactérie gram+ et sporulante, est l'agent de la loque américaine qui est l'une des maladies les plus importantes du couvain de l'Abeille domestique et qui cause le plus de dégâts. Les larves d'abeilles peuvent être facilement infectées par les spores des bactéries batonnets jusqu'à l'âge de deux jours. Ensuite, en avançant en âge, elles sont moins sensibles. Les abeilles adultes ne peuvent plus du tout être infectées ; elles sont devenues résistantes. Les spores, qui constituent le stade infectieux, sont transférées aux larves par les nourrices. Elles germent ensuite dans le tube digestif de la larve et s'y multiplient rapidement, causant la mort de la larve.

La résistance des larves à $P$. l. larvae a été étudiée en fonction de leur âge. Nous avons utilisé pour cette étude des larves âgées de deux, trois, quatre et cinq jours, ainsi que deux stades operculés. Nous avons produit un extrait des larves dans un mélange eau-éthanol (le nombre de larves variait en fonction de leur âge de façon à avoir toujours un échantillon de $130 \mathrm{~g}$ ), l'avons ajouté à un milieu de culture liquide (infusion de cerveau-cœur [Oxoid] ${ }^{\circledR}$ ) et inoculé avec $30 \mu \mathrm{L}$ d'une suspension de $P$. l. larvae ayant une extinction optique précise $(\mathrm{E}=0,22-$ $0,23)$. Après une période d'incubation de $24 \mathrm{~h}$ nous avons mesuré l'extinction optique à la longueur d'onde de $546 \mathrm{~nm}$, comme mesure de la croissance bactérienne.

Nos résultats montrent que les extraits des larves de deux, trois et quatre jours, sont capables d'inhiber la croissance de $P$. l. larvae à près de $80 \%$ par rapport à la croissance normale. L'effet inhibiteur des larves de cinq jours a varié entre 12 et $68 \%$. Nous n'avons pas pu trouver d'effet inhibiteur des stades operculés sur la croissance de la bactérie (Fig. 2). La méthode décrite peut constituer un outil utile pour discriminer des colonies plus ou moins résistantes.

Apis mellifera carnica / Paenibacillus larvae larvae / larve / résistance liée à l'âge

\footnotetext{
Zusammenfassung - Honigbienenlarven enthaIten eine Substanz die das Wachstum von Paenibacillus larvae larvae hemmt. Paenibacillus larvae larvae, ein gram-positives und sporenbildendes Bakterium, ist der Erreger der Amerikanischen Faulbrut. Diese ist eine der schwerwiegendsten und destruktivsten Erkrankungen der Bienenbrut. Die Honigbienenlarven können mittels der Sporen, des stäbchenförmigen Bakteriums sehr leicht bis zu einem Alter von zwei Tagen infiziert werden, aber mit zunehmenden Alter sind sie weniger anfällig.
}

Adulte Honigbienen können nicht infiziert werden; sie sind vollständig resistent.

Die Sporen, die das infektiöse Stadium darstellen, werden durch die Ammenbienen auf die Larven übertragen. Diese keimen dann im Darm der Larve aus, vermehren sich sehr rasch und verursachen somit den Tod der Larve.

Es wurde die Resistenz von unterschiedlichen Altersklassen von Larven gegen P. larvae larvae untersucht. Larven in einem Alter von zwei, drei, vier und fünf Tagen und zwei verdeckelte Larvenstadien wurden dazu verwendet. Wir stellten einen Ethanol-Wasser-Extrakt aus den Larven (unterschiedliche Anzahl von Larven, abhängig von ihrem Alter; mit zunehmenden Gewicht benötigt man weniger Larven um eine $130 \mathrm{mg}$ schwere Probe zu erhalten) her und fügten es einem flüssigen Nährmedium (Herz-Hirn-Bouillon Oxoid ${ }^{\circledR}$ ) bei und beimpften es mit $30 \mu \mathrm{l} P$. larvae larvae-Suspension mit einer definierten Extinktion $(E=0,22$ 0,23 ). Nach einem Inkubationszeitraum von 24 Stunden, wurde die Extinktion bei einer Wellenlänge von $546 \mathrm{~nm}$, als Maß für das Bakterienwachstum, gemessen.

Unsere Ergebnisse zeigen, daß der Extrakt aus den zwei-, drei- und viertägigen Larven die Fähigkeit besitzt, das Wachstum von P. larvae larvae im Mittel beinahe zu $80 \%$ des unbeeinflussten Wachstums zu hemmen. Der Hemmeffekt der fünf Tage alten Larven variiert, er reicht von 12 zu $68 \%$. Bei den verdeckelten Stadien konnten wir beinahe keine Hemmung auf das Bakterienwachstum feststellen (Abb. 2). Die beschriebene Methode könnte ein nützliches Werkzeug zur Diskriminierung von mehr oder weniger resistenten Völkern sein.

Apis mellifera carnica / Paenibacillus larvae larvae / Honigbienenlarven / altersabhängige Resistenz

\section{REFERENCES}

Bailey L., Lee D.C. (1962) Bacillus larvae: its cultivation in vitro and its growth in vivo, J. Gen. Microbiol. 29, 711-717.

Bamrick J.F. (1964) Resistance to American foulbrood in honey bees. V. Comparative pathogenesis in resistant and susceptible larvae, $\mathrm{J}$. Insect Pathol. 6, 284-304.

Bamrick J.F. (1967) Resistance to American foulbrood in honey bees. VI. Spore germination in larvae of different ages, J. Invertebr. Pathol. 9 , 30-34.

Bamrick J.F., Rothenbuhler W.C. (1961) Resistance to American foulbrood in honey bees. IV. The relationship between larval age at inoculation and mortality in a resistant and in a susceptible line, $\mathrm{J}$. Insect Pathol. 3, 381-390. 
Bíliková K., Wu G., Simúth J. (2001) Isolation of a peptide fraction from honeybee royal jelly as a potential antifoulbrood factor, Apidologie 32, 275-283.

Brødsgaard C., Ritter W., Hansen H. (1998) Response of in vitro reared honey bee larvae to various doses of Paenibacillus larvae larvae spores, Apidologie 29, 569-578.

Crailsheim K., Schneider L.H.W., Hrassni N., Bühlman G., Brosch U., Gmeinbauer R., Schöffmann B. (1992) Pollen consumption an utilization in worker honeybees (Apis mellifera carnica): dependence on individual age and function, J. Insect Physiol. 38, 409-419.

Crailsheim K., Riessberger-Gallé U. (2001) Honey bee age-dependent resistance against American foulbrood, Apidologie 32, 91-103.

Feldlaufer M.F., Knox D.A., Lusby W.R., Shimanuki H. (1993) Antimicrobial activity of fatty acids against Bacillus larvae, the causative agent of American foulbrood disease, Apidologie 24, 95-99.

Grimm M., Mossbeckhofer R. (1993) Untersuchung österreichischer Honige auf das Vorhandensein von Bacillus - larvae - Sporen, Bienenwelt 35, 185-190.

Hansen H. (1984a) Methodes for determining the presence of the foulbrood bacterium Bacillus larvae in honey, Tidsskr. Planteavl 88, 325328.

Hansen H. (1984b) The incidence of the foulbrood bacterium Bacillus larvae in honeys retailed in Denmark, Tidsskr. Planteavl 88, 329-336.

Haydak M.H. (1943) Larval food and development of castes in the honeybee, J. Econ. Entomol. 36, 778-792.

Haynes W.C. (1972) The catalase test. An aid in the identification of Bacillus larvae, Am. Bee J. 86, 14-34.

Heyndrickx M., Vandemeulebroecke K., Hoste B., Janssen P., Kersters K., De Vos P., Lognan N.A., Ali N., Berkeley R.C.W. (1996) Reclassification of Paenibacillus (formerly Bacillus) pulvifaciens (Nakamura 1984) Ash et al. 1994, a later subjective synonym of Paenibacillus (formerly Bacillus) larvae (White 1906) Ash et al. 1994, as a subspecies of $P$. larvae, emended description of P. larvae as $P$. larvae subsp. larvae and $P$. larvae subsp. pulvifaciens, Int. J. System Bacteriol. 46, 270279.

Hornitzky M.A.Z., Karlovskis S. (1989) A culture technique for the detection of Bacillus larvae in honeybees, J. Apic. Res. 28, 118-120.

Loidl A., Crailsheim K. (2001) Free fatty acids digested from pollen and triolein in the honeybee (Apis mellifera carnica Pollmann) midgut, J. Comp. Physiol. B 171, 313-319.

Myser W. (1954) The larval and pupal development of the honeybee Apis mellifera Linnaeus, Ann. Entomol. Soc. Am. 47, 545-711.

Ohe von der W., Dustmann J.H. (1997) Efficient prophylactic measures against American foulbrood by bacteriological analysis of honey for spore contamination, Am. Bee J. 137, 603-606.

Plageman O. (1985) Eine einfache Kulturmethode zur bakteriologischen Identifizierung von Bacillus larvae mit Columbia - Blut - Schrägagar, Berl. Münch., Tierärztl. Wschr. 98, 61-62.

Riessberger-Gallé U., Ohe von der W., Crailsheim K. (2001) Adult honeybee's resistance against Paenibacillus larvae larvae, the causative agent of the American foulbrood, J. Invertebr. Pathol. 77, 231-236.

Reiche R., Martin K., Möllmann U., Hentschel E.J. (1996) Beitrag zur Klärung der Resistenz der Bienenlarven gegen den Erreger der Amerikanischen Faulbrut Paenibacillus (vorher Bacillus) larvae (White 1906), Apidologie 27, 296-297.

Rinderer T.E., Rothenbuhler W.C. (1974) The influence of pollen on the susceptibility of honey - bee larvae to Bacillus larvae, J. Invertebr. Pathol. 23, 347-350.

Rothenbuhler W.C. (1964) Behaviour genetics of nest cleaning in honeybees. I. Responses of four inbred lines to disease - killed brood, Anim. Behav. 12, 578-583.

Rothenbuhler W.C., Thompson V.C. (1956) Resistance to American foulbrood in honey bees. I. Differential survival of larvae of different genetic lines, J. Econ. Entomol. 49, 470-475.

Stabe H.A. (1930) The rate of growth of worker, drone, and queen larvae of the honeybee, Apis mellifera Linn., J. Econ. Entomol. 23, 447-453.

Sturtevant A.P. (1924) The development of American foulbrood in relation to the metabolism of its causative organism, J. Agric. Res. 28, 129-168.

Tarr H.L.A. (1937) Studies on American foulbrood of bees. II. The germination of the endospores of Bacillus larvae in media containing embryonic tissues, Ann. Appl. Biol. 25, 633-640.

Wang D.-I. (1965) Growth rates of young queen and worker honeybee larvae, J. Apic. Res. 4, 3-5.

Woodrow A.W. (1942) Susceptibility of honeybees larvae to individual inoculations with spores of Bacillus larvae, J. Econ. Entomol. 35, 892-895.

Woodrow A.W., Holst E.C. (1942) The mechanism of colony resistance to American foulbrood, J. Econ. Entomol. 35, 327-330. 